\title{
Local Law-Based Rice Field Maintenance to Support Tourism Industry
}

\author{
I Ketut Widia \\ Faculty of Law \\ Universitas Warmadewa \\ Denpasar-Bali, Indonesia \\ ketut_widia@yahoo.co.id
}

\begin{abstract}
The phenomenon of the conversion of rice fields as agricultural land has become increasingly uncontrolled, where hundreds of hectares of productive rice fields are transformed into housing, hotels, villas, industrial centers, and so on. This study is aimed to identification the factors that cause the conversion of the agricultural lands. This research is concerned in the effectiveness of local laws in preventing the conversion of agricultural land to protect agricultural land. A statute and conceptual approach to legislation has been used in this study. The results showed that there are a number of rice fields that have been sold and used as residential, hospitality and industrial centers. However, it was found that some regions, especially in Bali has successfully applied local law known as Hukum Adat to preserve rice fields. It is expected that the government will pay particular attention to the farmers by providing facilities to support the efforts of farmers not to sell their land. In addition, it is possible for each village to transfer local laws to protect and conserve the rice fields.
\end{abstract}

Keywords—rice field protection; tourism; local law

\section{INTRODUCTION}

Tourism, as an human time reality, must be supported by at least industries, since it deals with providing good services for public, in which there is vital role of producers to draw on the attention of customers to not only purchase the quality and comfortability of services, such as taking into account of enjoying good facilities, but also afford the products, such as tourism consumable goods. Therefore, tourism as a living sector of human business, should be expanded with various approaches and techniques since it offers greatest challenges in the process of sustainability, including to discover technical ways to provide incorporation for preventative approaches, which covers at least sustaining the agricultural aspects [1].

Agriculture is in intimate linking to tourism, as if both with their natural potentials are combined, the linkage results in advantageous opportunity provision to conduct the benefits derived from the tourism with the rural poor living [2]. Rice fields and tourism industries are two types of agricultural entities, the source of community livelihoods that are interrelated and inseparable to each other. In terms of beauty, tourism can be flourished by rice fields that provide natural charm, attracting the tourists' interests to visit. From the standpoint of food productivity, rice fields are a natural resource that produces rice and various vegetables that is also too attractive for tourists during the visit to their destinations. Various agricultural products derived from rice fields are needed by the community and tourists for necessary, as in Indonesia, especially the province of Bali, as a place of leading destinations for tourists. Therefore, the existence of rice fields must be preserved; including the extent and fertility must be maintained and observed regularly and sustainably [3].

Maintenance of rice fields, as a productive agricultural land is not a process that is easy to do, because energy, thoughts, financial materials and creativity are needed. In addition, the minimalist understanding and awareness of the community to the law related to the preservation of agricultural lands is also part of the factors that inhibit the community's consistency and creativity in maintaining agricultural land, such as rice fields. For instance, a conspicuous view can be found when green areas of rice fields that are regulated and fixed by governments are often violated by communities whose lands are crossed with the attached green lines. This means the quality of the beauty of rice fields that are valuable tourism in the region is reduced so that the interest of tourists to visit is also reduced. For example, Lovina, the tourist area which is located in the north part of Bali. Initially, Lovina area is an area set by the government spreading natural and charming on the green rice fields at the time of post-planting rice. Unfortunately, the area has now turned into a row of housing that obliterates the beauty of panoramic rice fields. Consequently, the number of tourists who visited Lovina tourism area recently decreased and this brought a negative impact on the level of welfare for the local communities and the tourism industry in general.

Apparently, such problems in the Lovina area are an example of many emerged problems in tourism with negative effects on the decline in tourist visits of local and foreign tourists. What are the main factors that trigger the occurrence of such cases? Agricultural land is a potentially productive land and natural beauty serving to create enchant panoramic environment, so this natural function must be considered and conserved through various efforts of local government and society. Pretermission to care for and support agricultural activities, such as rice fields, has brought disadvantages to human life and the environment. Economic motivation is one of the reasons for people to sell their fields to investors for a place of business, given the extreme high price of land and the 
intention of local people to earn a lot of money in a rapid. This situation results in the transfer of rice fields to be used as places of business, such as hotels, housing and so forth.

Notwithstanding, various efforts need to be done in order to maintain and conserve the local natural cultural values possessed by certain community groups to ensure the survival of the era of globalization that is characterized by technology and science as it is today. Competitions in various sectors of life always occur and increasingly urge every tribe and country to take an active role by creatively maintaining and developing their respective cultures, including agriculture, such as rice fields. A number of varied attempts were made to maintain, conserve and develop national and regional development, including the provisions of national and local law. For that evidence, in this paper, identifying what the form and how the provisions and implementation of efforts to conserve rice fields according to local legal wisdom is the focus of discussion. Therefore, toward the exploration of the preservation of the rice fields, the problem is raised, namely "What are effective techniques to establish local law so as to impact on the obedience and loyalty of local community members?"

\section{METHOD}

To establish the objectives in this study, statute and conceptual approaches to legislation were guided. Arguments concerning the establishment of local law to realize the efforts of conservation of rice fields as a driver of tourism activities are explored and discussed through a study based on the national law of the government (statute approach), namely the legislation on tourism as a consideration and a foothold in formulating local laws. In addition, the empirical views of the phenomenon occurring in the rice field sector with great potential to support tourism in Bali, is used as a basis for building argumentation on the formation of local law, so that the conceptual approach is formulated.

The data analyzed in this paper are obtained from Indonesian republic legislation and provincial government regulations of Bali on agricultural land and tourism (primary legal sources). In addition, studies on agricultural land and tourism, which include international books and journals, have been referred to as guidelines for developing ideas in the effort to establish local law to safeguard and conserve farmland to support tourism activities to increase measurable quality values through the number and frequency of visitors coming (secondary legal sources).

\section{RESUlt AND DiscUSSION}

\section{A. National Law-Based Farm Protection}

It has become an absolutely inevitable fact that every year agricultural land is increasingly reduced in number as a significant result of land conversion processes which tend to be done without good planning properly. There are a number of rice fields whose functions have been transformed into residential areas, large industrial centers, and hospitality. Central and local governments have been trying to issue many regulations related to maintaining the development of rice fields (not for not for transfers), but often ignored by the community. As empirical evidence, it can be seen that there are a number of fertile agricultural land that is now filled with large buildings as places where various types of businesses take place on.

Consequently, conversion of agricultural land occurs as a result of the growing number of people and the increasing number of rapid development in various sectors of human life [4]. In addition, business competition, especially foreign investments in Indonesia, is also a major factor in the conversion process of agricultural land among local communities. The desire to equalize the life amid the cycle of development progress, patterns and lifestyles of people in the era of globalization through the acquisition of a lot of money also includes the trigger factor of public intention to sell the land, especially rice fields, because on the sale of land, a sum of money is obtained in large amounts, depending on the shape and size of the land [5].

In all conscience, law on agricultural land has been regulated, such as Republic of Indonesia Law no. 41 of 2019 Article 57 1-6 on Sustainable Land Farming Protection, where in this section of law, sanctions for perpetrators of irregularities in the function of agricultural land have been regulated. However, the fact testifies that this law is not overwhelmed by local people in some villages, especially in the area of Bali. One of the causes of people's indifference to the regulation is the idea that tolerance can always be given because the land sold to foreign citizens is their own private land. It is predictable that public awareness to comply with government regulations in the land sector is so low that strict regulations close to their daily lives are needed, such as customary law or local law within the village.

Again, the conversion of agricultural land, which occurs among the local community in Bali, is an economic case, the majority of which is derived from the interest and desire of the people to earn and have a lot of money for the fulfillment and satisfaction of their respective needs. The impatience of society in obtaining its financial needs is a problem that is almost uncontrollable, especially regarding the living conditions in urban areas; everyone is implicitly required to be competitive. In addition, it was found that public awareness of the law was also demonstrated through the transfer of land functions, namely that the regulation established by the government on the preservation of agricultural land that is a source of local community wisdom is often ignored.

\section{B. Local Law-Based Protection of Rice Field}

Given the positive laws relating to the preservation of rice fields are firmly ignored and disobeyed by the community, a new idea in order to protect the area of rice fields emerged, namely forming a local law known as Hukum Adat (customary law), namely awig-awig, that specifically regulates by ignoring the public to arbitrarily make sales of rice fields to investors. Awig-awig is a device containing a sequence of customary laws and regulations in every Desa Pakraman in Bali [6]. In addition, Desa Pakraman is a unit of customary law community in Bali Province which has one unity of tradition and manners of social interaction of Hindu community from generation to generation in Kahyangan Tiga or Kahyangan 
Desa which has certain territory and own property and is entitled to take care of their own household. This, in a nutshell, arises as a result of the premise that a unity of society in a particular group is entitled to manage and set its own family, so it is understood that a certain set of rules and/or legal provisions is required as a guide in running the wheel of household life of every member of the community of Desa Pakraman. The results of researches that have been done on efforts to preserve tourism showed that the model of preservation of rice fields to support food security and tourism industry is quite successful significantly. In addition, in some areas of Bali, there are some villages that have effectively implemented local laws so that agricultural land remains sustainable and can be a very interesting tourist attraction. For example, in Jatiluwih village, Tabanan regency, Bali, local laws are drafted and stipulated as an absolute rule must be followed through deliberation and consensus jointly by the community itself and for the community has succeeded and successfully protected the existing rice fields in the region to this day.

The enactment of these provisions is made on with the spirit to make all the rice fields in the village remain preserved so that it can become "eternal rice" with its intact form. That is, the existing rice field area forever will be a rice field with a natural nature; will not switch functions into housing, hotels, and or other buildings. The perceived consequence of public awareness on obeying local law is the area of rice fields becomes sustainable and beautiful. All of these have a positive impact on the number of tourist visits to this village which every day increasingly grown. Unimaginable, President of the United States, Michael Obama once took time to visit Jatiluwih to enjoy the very beautiful and charming scenery of rice fields.

Another example that successfully enforces local laws to safeguard and conserve agricultural land, especially rice fields is the tourist area of Ceking in Ubud, Gianyar, Bali. In this village, people understand and realize the importance of natural beauty based on rice field area. In the village of Ceking, there is no society that sells rice fields, but what is sold to tourists is the natural beauty of the terraced, beautiful, and very fascinating rice field terraces. Thus, maintaining rice fields is very important to do in order to support the tourism industry and maintain food security for the community. Meanwhile, local law must be established and empowered in order to make it happen effectively.

Discussing the local law, there are several stages that must be done so that the local law in question can run effectively in the community. The stages are:

- Conducting academic studies. At this stage, community leaders along with experts from campus, conduct surveys and studies of the will of the community in general. The question posed focused on whether the community is interested in maintaining the area of interest. Previous understanding of the importance of maintaining rice fields for the sake of community food security is certainly given.

- Drafting local laws. After conducting an academic study, then drafted a local law regulating the sustainability of the rice fields. At this stage the academic role of the campus as a legal expert remains necessary.

- Establishing a local legal drafting team. At the third stage, local law drafts already established by jurists were formulated to become a permanent and intact local law.

- Conducting socialization to the community. In order not to have people who feel not invited or feel not involved in the deliberation of local law formation, socialization becomes very important. At this stage all the rules made are submitted to the community so that the whole community knows and understands the purpose of enactment of the local law in question.

- Accommodating people's aspirations. The fifth stage is a very important stage of all that exists. At this stage the community is invited to deliberation, the will of the community is accommodated and accepted to complement the shortcomings of the local law draft that has been made.

- Holding meetings with the whole community. A joint meeting in this case is a meeting aimed at refining things that may be less favorable to some parts of society.

- Announcing the enactment of local law. The announcement stage of the implementation of local law is very important to do. All communities are invited to explain that the established local laws will begin to be implemented. Usually, an actual day to do this announcement event is selected.

- Conduct a sacred ritual of local law. This sacralization ritual is also a very important thing to do because in accordance with the theory of the application of religious values in local laws that regulate that the implementation of local law, the ceremony gives strength to local laws that will be applied to the community should be done.

- Begin to apply the local laws for the conservation of paddy fields.

\section{CONCLUSION}

Every sector in human life does basically need guidance that contains rules to ensure the comfort and well-being of the community. Similarly, the agricultural sector is expected to be tourism potential in Bali to expect real action from humans as creators of natural resources management to make conservation efforts because its products are felt and enjoyed by human managers themselves. However, from various efforts that have been done, they are able to ensure the safety of the environment. One of the effective efforts that need to be done has been discussed throughout this paper. From the facts obtained, some conclusions can be drawn, such as the establishment of local law in order to provide protection against the existence of local law-based field areas conducted with the local community in deliberation to reach consensus. Customary sanctions for violating agreements already set forth 
in customary law must be done consistently, firmly, forcefully, and non-discriminatory. In addition, evaluation of the implementation of local law that has been agreed must always be done; the improvement may be done in accordance with the conditions confronted within society.

Hence, based on the sail obtained in this study, farmers are expected to stick to their traditions and professions as farmer, because if farmland is well managed, irrigation is always sufficient, balanced fertilization, and good post-harvest, it is certain that farmers live more prosperous. One of the techniques in applying the local law is by preserving the activities of tradition in the Subak organization and the implementation of religious ceremonies in Candi Subak. When people celebrate their religious ceremonies, it means that visitors will be watching the tradition. That means it will protect the fields and in the same time, it will develop the tourism industry.

Additionally, the government, both central government and local governments throughout Indonesia are expected to provide special intensive to farmers as a form of protection of agricultural land. Thus the interest of the farmers to sell their rice fields becomes non-existent.

\section{ACKNOWLEDGEMENT}

The author would like to thank all the parties who have helped and contributed in the writing of this article, both those who contribute in the form of funding and critical ideas. Hopefully this paper can be useful theoretically and practically for the addition and development of knowledge, especially in the field of legal science.

\section{REFERENCES}

[1] Budeanu, A., Impacts and responsibilities for sustainable tourism: A tour operator's perspective. Journal of Cleaner Production, 13(2), 89-97. 2005.

[2] Gurung, L., Exploring Links between Tourism and Agriculture in Sustainable. 2012.

[3] Brščić, K., the Impact of Agrotourism on Agricultural Production Utjecaj Agroturizma Na Poljoprivrednu Proizvodnju. First International Conference on Agriculture and Rural Development, 7(3), 559-564. 2006.

[4] Kusniati, R., Analisis Perlindungan Hukum Penetapan Lahan Pertanian Pangan Berkelanjutan. INOVATIF Jurnal Ilmu Hukum. 2013.

[5] Hutagalung, A. S., Kolkman, wilbert D., Verstappen, L. C. A., Nurlinda, I., Parwitasari, H., Qadariani, M., Vonck, F. J., Hukum pertanahan di belanda dan indonesia. 2012.

[6] Gunawan, D. H., Perubahan Sosial di Pedesaan Bali (Doctoral dissertation, Doktor Studi Pembangunan Program Pascasarjana UKSW). 2013. 